\title{
BACTERIAL SURVIVAL RATE ON TOOTHBRUSHES AND THEIR DECONTAMINATION WITH ANTIMICROBIAL SOLUTIONS
}

\author{
TAXA DE SOBREVIVENCIA BACTERIANA EM ESCOVAS DENTAIS \\ E SUA DESCONTAMINAÇÃO COM SOLUÇÕES ANTIMICROBIANAS
}

\begin{abstract}
Sandra SATO ${ }^{1}$, Izabel Yoko ITO ${ }^{2}$, Elza Helena Guimarães LARA ${ }^{3}$, Heitor PANZERI ${ }^{4}$ Rubens Ferreira de ALBUQUERQUE JUNIOR ${ }^{5}$, Vinícius PEDRAZZI ${ }^{5}$
\end{abstract}

1- Graduate Student (Master degree) Dept. of Dental Materials and Prosthesis, Ribeirão Preto Dental School - University of São Paulo. 2- Associate Professor, Dept. of Clinical, Toxicological and Bromatological Analysis -Pharmaceutical Sciences School of Ribeirão Preto University of São Paulo.

3- Associate Professor, Dept. of Pharmaceutical Sciences, Pharmaceutical Sciences School of Ribeirão Preto - University of São Paulo.

4- Associate Professor, Dept. of Dental Materials and Prosthesis, Ribeirão Preto Dental School - University of São Paulo.

5- Assistant Professor, Dept. of Dental Materials and Prosthesis, Ribeirão Preto Dental School - University of São Paulo.

Corresponding address: Vinícius Pedrazzi - Faculdade de Odontologia de Ribeirão Preto - Universidade de São Paulo - Departamento de Materiais Dentários e Prótese - Av. do Café s/nº - Bairro Monte Alegre - Ribeirão Preto - SP 14040-904 - Phone: 0-XX-16-602-4008

Fax: 0-XX-16-633-0999 - e-mail: pedrazzi@forp.usp.br

Received: January 20, 2003 - Returned for modification: May 12, 2003 - Accepted: January 29, 2004

\begin{abstract}
$T$

he purpose of this study was to evaluate bacterial survival rate on toothbrushes after brushing and the efficacy of their decontamination by spraying antimicrobial solutions. Thirty subjects were instructed to spray the solutions on toothbrush bristles after brushing. Each volunteer tested three sprays, one solution per week; the sprays were labeled spray 1 (cetylpyridinium chloride - CPC - and basic formulation), 2 (basic formulation only) and 3 (control - sterile tap water). At the end of each week, the brushes were collected and sonicated in Letheen Broth ${ }^{\circledast}$; the suspensions were ten-fold diluted and the dilutions were plated on various culture media. Anaerobic bacteria, evaluated by colony count of black pigment producing organisms on Ask medium, were recovered from $83.3 \%$ of the samples, Streptococci from $80 \%$ and aerobic Gram-negative bacilli from $46.7 \%$ of them in the control tests. There was a significant decrease in toothbrush contamination with antimicrobial sprays 1 and 2, the first showing the greatest decrease on bacterial counts.

UNITERMS: Toothbrushing; Microbial survival; Decontamination; Cetylpyridinium chloride.
\end{abstract}

\section{RESUMO}

propósito deste estudo foi avaliar a taxa de sobrevivência bacteriana em escovas dentais após a escovação e a eficácia na sua descontaminação pelo borrifamento de soluções antimicrobianas. Trinta indivíduos foram instruídos a borrifar as soluções nas cerdas das escovas após a escovação. Cada voluntário testou três sprays, uma solução por semana; os sprays foram rotulados spray 1 (cloreto de cetilpiridínio - CCP - e formulação básica), 2 (formulação básica apenas) e 3 (controle - água de torneira esterilizada). Ao final de cada semana, as escovas eram recolhidas e introduzidas no caldo Letheen ${ }^{\circledR}$, submetidas a ultra-som, à diluição decimal seriada e as suspensões semeadas em vários meios de cultura. As bactérias anaeróbias, avaliadas pela contagem de colônias de microrganismos produtores de pigmento negro no meio Ask, foram recuperadas em 83,3\% das amostras, estreptococos em $80 \%$ e bacilos aeróbios Gram-negativos em 46,7\% das amostras nos testes controle. Houve uma significante redução na contaminação das escovas dentais com os sprays antimicrobianos 1 e 2 , o primeiro mostrando maior redução nas contagens de bactérias.

UNITERMOS: Escova dentária; Microorganismos, sobrevivência; Descontaminação; Cloreto de cetilpiridínio. 


\section{INTRODUCTION}

Toothbrushes may become heavily contaminated with microorganisms. These microorganisms may originate not only from the oral cavity ${ }^{17,27,29}$ but also from the environment where the toothbrushes are stored ${ }^{16}$.

This contamination implicates in the possibility of reinfection of a patient by toothbrushes harboring pathogenic microorganisms. Cobb ${ }^{4}$ (1920) was the first investigator to report the recurrence of mouth infection that extended to the throat. When the patient was advised to soak his toothbrush in alcohol before and after using it, the patient recovered from the disease. Glass and Lare ${ }^{8}$ observed a correlation between contaminated brushes and the presence of diseases. Later, Glass and Shapiro ${ }^{10}$ concluded that regardless of the nature of the disease, patients could achieve elimination of the symptoms and disease by just changing the toothbrush.

Besides the problem of reinfection with microorganisms, contaminated toothbrushes may act as reservoirs for microorganisms originating from the environment where they are stored. Malmberg, et al. ${ }^{17}$ reported heavy growth of enterics, yeasts and molds in toothbrushes used by children in a daycare center. Coliforms were also found in toothbrushes ${ }^{16,27,29}$ and their origin presumably is the toilet. Procedures for decontamination of toothbrushes would prevent the risks of reinfection or infection by other pathogenic microorganisms from the environment.

Soaking the toothbrush in alcohol was one of the first recommended procedures for toothbrush disinfection in $1920^{4}$. Later, in 1929, Kauffmann ${ }^{13}$ listed some methods for sanitation and drying of toothbrushes such as sunlight and table salt to absorb their moisture and to keep the brush inside a closed container with a preparation containing formaldehyde gas for its disinfection.

Other methods included the use of ultraviolet light ${ }^{6,9}$, immersion in a disinfecting solution ${ }^{1,14,21,24}$, spraying of antimicrobial solutions on the bristles ${ }^{18-20}$, use of a microwave oven $^{3}$ and washing of the toothbrush in a dishwasher ${ }^{30}$. The impact of toothpastes on toothbrush microbial contamination was investigated by some authors ${ }^{22,23}$, while the efficacy of the incorporation of an antimicrobial substance in the toothbrush to avoid bacterial contamination was assessed in other studies $^{22,26}$.

The purpose of this study was to evaluate the effectiveness of sprays containing antimicrobial solutions in the disinfection of toothbrushes contaminated by microorganisms in vivo.

\section{MATERIAL AND METHODS}

Thirty subjects, ranging from 23 to 56 years of age (15 males and 15 females) with at least 20 teeth were enrolled into this study. Informed consent was obtained using a form that was approved by the Ethics Committee at the University of Sao Paulo, Ribeirão Preto Dental School (Process \# 2000.1.206.58.1). None of the subjects was using antimicrobials during this study.

Each of the 30 volunteers blind-tested three solutions named sprays 1, 2 and 3. All the subjects used the same solution for a period of one week for each spray. Table 1 shows the composition of the sprays.

At the beginning of the week every subject received a new multi-tufted toothbrush with soft nylon tufts (Kolynos Standard $^{\circledR}$, Kolynos, São Bernardo do Campo-SP, Brazil), a tube of toothpaste (Sorriso ${ }^{\circledR}$, Kolynos, São Bernardo do Campo-SP, Brazil) and one of the three sprays. After the use, all toothbrushes were rinsed under running tap water and the subjects were oriented to spray the solution on the bristles six times, removing the excess solution by shaking the brush. The toothbrushes were rinsed again under tap water before each use to remove any remaining solution.

The toothbrushes and the used sprays were collected at the end of one week. The toothbrushes were held on a rack that avoided contact among the bristles and this rack was put into a box for transportation to the laboratory. New toothbrushes were given to the volunteers to be used with one of the remaining sprays until all the subjects used all three sprays. The brushes were coded so that the microbiological analysis could be performed blindly.

All samples were processed after four hours from the last use. Each toothbrush was aseptically introduced in a test tube with 10.0mL of Letheen Broth (Difco Laboratories, Detroit MI, USA) in such a manner that only the head and bristles were immersed, and the tube with the toothbrush was subjected to sonication for 5 seconds (Thornton-Inpec Eletrônica, Vinhedo - SP, Brazil). After the removal of the toothbrush, the resultant suspensions were ten-fold diluted in phosphate buffered saline (PBS) and aliquots of $10.0 \mu \mathrm{L}$ were plated using the drop plate technique ${ }^{12}$ in culture media that included: Askblood agar supplemented with 3 to $5 \%$ defibrinated rabbit blood, $5 \mu \mathrm{g} / \mathrm{mL}$ hemin and $1 \mu \mathrm{g} / \mathrm{mL}$ menadione (vitamin $\mathrm{K}$ ), for anaerobes ${ }^{28}$; As - blood agar, with 3 to 5\% defibrinated rabbit blood, for total aerobic count; Ms - Mitis Salivarius Agar ${ }^{\circledR}$ (Difco), for total oral streptococci and EAM - Eosin Methylene Blue Agar $^{\circledR}$ (Oxoid, Basingstoke - Hampshire, England), for

TABLE 1- Composition of the tested solutions

\begin{tabular}{|c|c|c|c|}
\hline \multirow[t]{2}{*}{ Components (\%) } & \multicolumn{3}{|c|}{ Spray } \\
\hline & 1 & 2 & 3 \\
\hline propyleneglycol $^{1}$ & 30.00 & 30.00 & - \\
\hline methylparaben (Nipagin) ${ }^{2}$ & 0.16 & 0.16 & - \\
\hline propylparaben (Nipazol) ${ }^{3}$ & 0.02 & 0.02 & - \\
\hline polyvinylpyrrolidone $\mathrm{K}^{3} 0^{4}$ & 0.02 & 0.02 & - \\
\hline ethyl alcohol ${ }^{5}$ & 10.00 & 10.00 & - \\
\hline cetylpyridinium chloride ${ }^{6}$ & 0.05 & - & - \\
\hline distilled water (q.s.) (mL) & 100.00 & 100.00 & - \\
\hline sterile tap water (mL) & - & - & 100.00 \\
\hline
\end{tabular}

1, 2, 3, 5 Ely Martins, Ribeirao Preto - SP, Brazil

${ }^{4}$ Goldlab, Ribeirao Preto - SP, Brazil

${ }^{6}$ Labsynth, Diadema - SP, Brazil 
aerobic Gram-negative bacilli. The Ask plates were incubated at $37^{\circ} \mathrm{C}$ in anaerobiosis with Anaerobac ${ }^{\circledR}$ (anaerobic system envelope, Probac, São Paulo - SP, Brazil) for at least 5 days; As and $E A M$ were incubated aerobically at $37^{\circ} \mathrm{C}$ for $24-48 \mathrm{hr}$ and $M s$ at $37^{\circ} \mathrm{C}$ in microaerophilic conditions in a candle jar system for 2 to 3 days. After the incubation period, the number of colony forming units was counted using a stereomicroscope (Nikon, Japan) under reflected light and the CFU/mL was determined. The microorganisms were identified based on colony morphology and Gram staining of the colony developed on selective culture media, for a specific group of bacteria.

The original data was analyzed with the GraphPad Prism software, version 3.03 for Windows (GraphPad Software, San Diego-CA, USA, http://www.graphpad.com). The Friedman test $^{7}$, a nonparametric test, was used to compare the three spray groups as the data did not follow the Gaussian distribution, even after transformation. To identify what spray differed from the others, Dunn's multiple comparison procedure ${ }^{5}$ was performed. An alpha level of 0.05 was accepted for significance.

\section{RESULTS}

Table 2 summarizes the results obtained in this study. Growth of microorganisms recovered from toothbrushes treated with the control spray (water) occurred on Ask, Ms, As and EAM plates on 83.3, 80.0, 73.3 and 46.7 per cent of the toothbrushes, respectively. Anaerobic growth, evaluated by colony count of black pigment producing organisms on Ask medium, were observed in cultures from toothbrushes of $83.3 \%$ of the samples with a mean of $1.0 \times 10^{6} \mathrm{CFU} / \mathrm{mL}$ (range $0-1.7 \times 10^{7} \mathrm{CFU} / \mathrm{mL}$ ) while aerobic Gram-negative bacilli recovered in $E A M$ were the least frequent microorganisms found (46.7\%) with a mean of $1 \times 10^{6}$ CFU/mL (range 0-1.6×107 CFU/mL).

The Friedman test showed a significant difference among the three sprays tested for all groups of microorganisms studied ( $p<0.0001$ ). When the pairs of sprays were compared by the Dunn's post test, sprays 1 and 2 did not show a significant difference for any of the microorganisms investigated. Despite this result, a reduction in the contamination level of the toothbrushes was observed when sprays 1 and 2 were both compared with spray 3 . There was a statistically significant difference ( $p<0.05$ ) between the comparisons of sprays $1 \times 3$ and 2x3 for anaerobic count, aerobic count and streptococci. For aerobic Gram-negative bacilli, only spray 1 (mean $=0$, range $=0-0$ ) was significantly different from 3 (mean $=1 \times 10^{6} \mathrm{CFU} / \mathrm{mL}$, range $=0-1.6 \times 10^{7} \mathrm{CFU} / \mathrm{mL}$ ).

\section{DISCUSSION}

There is little public awareness that toothbrushes may become contaminated by microorganisms with use. This contamination had already been well documented ${ }^{16,17,27,29}$, and a contaminated toothbrush can be the cause of reinfection of a person with pathogenic bacteria ${ }^{4,8,10}$ or can be the reservoir for environmental microorganisms ${ }^{16,17,27,29}$. Methods for toothbrush disinfection have been searched in order to avoid such events.

This study evaluated the effectiveness of sprays containing antimicrobial solutions in the disinfection of contaminated toothbrushes.

TABLE 2- Frequency of positive samples and mean of microorganisms isolated from the toothbrushes

\begin{tabular}{|c|c|c|c|}
\hline microbial groups & spray & $\mathrm{n}^{\circ}$ of positive samples (\%) & mean $^{1}$ \\
\hline \multirow[t]{3}{*}{ Anaerobes (bpb) } & $1^{\mathrm{a}}$ & $5(16.7)$ & $6.3 \times 10^{2}$ \\
\hline & $2^{a}$ & $15(50.0)$ & $5.8 \times 10^{4}$ \\
\hline & $3^{b}$ & $25(83.3)$ & $1.0 \times 10^{6}$ \\
\hline \multirow[t]{3}{*}{ Aerobes } & $1^{\mathrm{a}}$ & $6(20.0)$ & $4.5 \times 10^{2}$ \\
\hline & $2^{a}$ & $8(26.7)$ & $1.1 \times 10^{4}$ \\
\hline & $3^{b}$ & $22(73.3)$ & $2.6 \times 10^{6}$ \\
\hline \multirow[t]{3}{*}{ Streptococci } & $1^{a}$ & $5(16.7)$ & $3.5 \times 10^{2}$ \\
\hline & $2^{a}$ & $11(36.7)$ & $1.4 \times 10^{4}$ \\
\hline & $3^{b}$ & $24(80.0)$ & $1.6 \times 10^{6}$ \\
\hline \multirow[t]{3}{*}{ Aerobic Gram-negative bacilli } & $1^{\mathrm{a}}$ & $0 \quad(0.0)$ & 0 \\
\hline & $2^{\mathrm{ab}}$ & $2(6.7)$ & $7.0 \times 10^{2}$ \\
\hline & $3^{b}$ & $14(46.7)$ & $1.0 \times 10^{6}$ \\
\hline
\end{tabular}

Spray numbers followed by different superscript letters are significantly different as determined by Dunn's procedure $(p<0.05)$

1 in CFU/mL 
Besides total aerobic count, selective culture media were chosen considering the relevance of aerobic and anaerobic oral microorganisms. Black pigmented colonies on Ask medium were considered anaerobic bacteria, even though respiratory test had not been performed. Species of black pigment producing anaerobic Gram-negative rods, including Porphyromonas, Prevotella and Bacteroides are strongly associated with periodontal diseases ${ }^{11,25}$. Streptococci, which were not identified to the species level in this work, were isolated because they are dominant members of oral microbiota, including in this group some important species for Dentistry, such as Streptococcus mutans and Streptococcus sobrinus, etiological agents of tooth decay ${ }^{2,15}$.

The highest microbial contamination was found with spray 3 , containing only water. This group represented the most common hygienic measure that is taken with toothbrushes, which is only rinsing in tap water. The same results were seen in previous studies ${ }^{20,21}$.

Spray 1 was composed of cetylpyridinium chloride (CPC) and a basic formulation that contained preservatives, vehicle and distilled water, while spray 2 had only the basic formulation. Both showed a statistically significant reduction in microbial contamination when compared to spray 3 (control - tap water) for the tested microorganisms. The only exception was observed in the comparison between sprays 2 and 3 for Gramnegative bacilli, with no significant differences.

The results of the basic formulation may be due to the presence of substances with antimicrobial activity, such as methylparaben and propylparaben, both preservatives of the solution, and to the presence of alcohol (solvent). Sanches, et al. ${ }^{24}$ used alcohol for toothbrush disinfection and observed a microbial reduction with it. Alcohol had already been recommended for toothbrush disinfection ${ }^{4}$. The sum of substances with antimicrobial activity could have transformed a small antimicrobial effect into a great one. Lara, et al. ${ }^{14}$ verified that the association of antimicrobial agents can increase the activity against microorganisms in an in vitro study.

Another component that could explain the efficacy of the basic formulation is polyvinylpyrrolidone, a film-former substance. This component might have extended the contact time of sprays 1 and 2 with the bristles, forming a coating with the dehydration of the solution on them.

The results showed less contamination when using spray 1 in comparison with spray 2, with a lower number of CFU/mL when CPC was added to the solution, although the difference was not significant at the $5 \%$ level. Although the statistical analysis did not reveal differences between sprays 1 and 2, the results showed less contamination, with fewer bacteria, when CPC was added to the solution. This was especially true with Gram-negative bacilli, when only spray 1 was statistically better than water; the same was not observed with spray 2.

Other authors have studied CPC as a disinfecting solution for the immersion of toothbrushes. Caudry, et al. ${ }^{1}$ tested the effect of anti-infective agents against aerobic microorganisms dislodged from toothbrush bristles contaminated in vivo. One of the agents was $\mathrm{Cepacol}^{\circledR}$, an antiseptic solution containing CPC in its composition. Cepacol ${ }^{\circledR}$ promoted a 100 per cent killing effect of all dislodged bacteria from the toothbrushes after a 20-minute exposure. In their study, the solution was applied on the dislodged microorganisms, not directly on the toothbrushes, like in our work. This effect was not obtained in our study. Otherwise, the authors did not evaluate any anaerobic growth, which were prevalent in the present investigation. In another investigation, CPC was also used for toothbrush disinfection ${ }^{24}$. The results showed only a slight reduction in the amount of viable microorganisms for total streptococci, while in our study the decrease for this group of bacteria was more striking. This divergence might be caused by the different composition of the CPC solutions tested in each work and by the time of toothbrush use before the microbiological analysis, which was carried out after 2 months of use ${ }^{24}$ and after a period of one week in the currently discussed study. This extended period of use might be responsible for the greater contamination found in that study ${ }^{24}$. On the other hand, microbiological analysis is dependent on methodological accuracy and crucial technical details are often omitted, what makes difficult comparing results.

In spite of the use of CPC for toothbrush decontamination, the previously discussed studies ${ }^{1,24}$ did not use the same means for applying the antimicrobial solution as in the present investigation. Other studies tested in vitro ${ }^{19}$ and in vivo ${ }^{20}$ a commercial preparation in a spray form, showing efficacy of this spray for toothbrush disinfection. In the case of these previous studies, activated ethanol and parabens were the components responsible for the disinfecting action. The only study that used a CPC solution in a spray form was conducted by Meier, et al. ${ }^{18}$. They contaminated toothbrushes in vitro with Candida albicans and Staphylococcus epidermidis. Toothbrushes treated with a spray designed for toothbrush disinfection with CPC as the active ingredient showed a significant reduction in bacterial and fungal growth when compared with brushes not treated with CPC. In our study, toothbrushes were contaminated in vivo and there was a wider range of microbial groups investigated. The good results obtained by Meier, et al. ${ }^{18}$ with a CPC spray for toothbrush disinfection were confirmed in the present investigation.

We do not intend to encourage people to increase antimicrobial consumption but to offer them eventual and useful approach for reducing toothbrush contamination.

This is a preliminary study in which we could evaluate the degree of toothbrush bacterial contamination and disinfection efficacy based on quantitative reduction of bacterial growth. One limitation of these findings is that the investigation did not consider all the varieties of microorganisms present in the oral cavity. Further investigations should take into account survival of other microorganisms, such as fungi and viruses.

\section{CONCLUSION}

According to the results, obligate anaerobes and aerobes were recovered from toothbrushes after brushing and sprays containing CPC and the basic formulation proved to be eventual and useful approaches for reducing toothbrush contamination. 


\section{ACKNOWLEDGMENTS}

This study was partially supported by CNPq (Conselho Nacional de Desenvolvimento Científico e Tecnológico), grant 130379/2001-8

\section{REFERENCES}

1- Caudry SD, Klitorinos A, Chan ECS. Contaminated toothbrushes and their disinfection. J Can Dent Assoc 1995; 61:511-6.

2- Caufield PW, Cutter GR, Dasanayake AP. Initial acquisition of mutans streptococci by infants: evidence for a discrete window of infectivity. J Dent Res 1993; 72:37-45.

3- Chibebe Jr J, Pallos D. Avaliação da esterilização de escovas dentais em forno de microondas (estudo in vitro). Rev Biociênc 2001; 7:3942 .

4- Cobb CM. Toothbrushes as a cause of repeated infections of the mouth. Boston Med Surg J 1920; 183:263-4.

5 - Dunn OJ. Multiple comparisons using ranking sums. Technometrics 1964; 6:241-52.

6- Fratto G, Nazzicone M, Ortolani E. Disinfezione degli spazzolini dentali. ricerca sperimentale. Prev Assist Dent 1986; 16:7-10.

7- Friedman M. The use of ranks to avoid the assumption of normality implicit in the analysis of variance. J Am Stat Assoc 1937; 32:675701.

8- Glass RT, Lare MM. Toothbrush contamination: a potential health risk? Quintessence Int 1986; 17:39-42.

9- Glass RT, Jensen HG. The effectiveness of a u-v toothbrush sanitizing device in reducing the number of bacteria, yeasts and viruses on toothbrushes. J Okla Dent Assoc 1994; 84:24-8.

10- Glass RT, Shapiro S. Oral inflammatory diseases and the toothbrush. J Okla Dent Assoc 1992; 82:30-2.

11- Haffajee AD, Socransky SS. Microbial etiological agents of destructive periodontal diseases. Periodontol 2000 1994; 5:78-111.

12- Herigstad B, Hamilton M, Heersink J. Optimal design of the drop plate method for enumerating bacteria. In: Biofilms 2000 (B2K); 2000 Jul. 16-20; Big Sky, Montana. Big Sky: American Society for Microbiology; 2000. p. 57., abstract 117.

13- Kauffman JH. A study of toothbrush II. Dental Cosmos 1929; 71:132-40.

14- Lara EHG, Ito IY, Ogasawara MS, Semprini M, Panzeri H. Avaliação da eficiência de algumas soluções anti-sépticas para sanitização de escovas dentais. Rev ABO Nac 2001; 9:18-23.

15- Loesche WJ. Role of Streptococcus mutans in human dental decay. Microbiol Rev 1986; 50:353-80.

16- Long SR, SantosAS, Nascimento CMO. Avaliação da contaminação de escovas dentais por enterobactérias. Rev Odontol Univ Santo Amaro 2000; 5:21-5.
17- Malmberg E, Birkhed D, Norvenius G, Norén JG, Dahlén G. Microorganisms on toothbrushes at day-care centers. Acta Odontol Scand 1994; 52:93-8.

18- Meier S, Collier C, Scaletta MG, Stephens J, Kimbrough R, Kettering JD. An in vitro investigation of the efficacy of CPC for use in toothbrush decontamination. J Dent Hyg 1996; 70:161-5.

19- Neal PR, Rippin JW. The efficacy of a toothbrush disinfectant spray - an in vitro study. J Dent 2003; 31:153-7.

20- Nelson Filho P. Eficácia de diferentes soluções na desinfecção de escovas dentais de crianças de 24 a 48 meses: Estudo clínico randomizado (cultura microbiana e MEV) e teste de difusão em ágar. Ribeirão Preto; 2003. [Tese de Livre Docência - Faculdade de Odontologia de Ribeirão Preto da USP].

21- Nelson Filho P, Macari S, Faria G, Assed S, Ito IY. Microbial contamination of toothbrushes and their decontamination. Pediatr Dent 2000; 22:381-4.

22- Quirynen M, De Soete M, Pauwels M, Gizani S, Van Meerbeek, Van Steenberghe D. Can toothpaste or a toothbrush with antibacterial tufts prevent toothbrush contamination? J Periodontol 2003; 74:31222.

23- Quirynen M, De Soete M, Pauwels M, Goossens K, Teughels W, Van Eldere J, et al. Bacterial survival rate on tooth- and interdental brushes in relation to the use of toothpaste. J Clin Periodontol 2001; 28:1106-14.

24- Sanches MH, Peres SHCS, Peres AS, Bastos JRM. Descontaminação das escovas dentárias por imersão em soluções anti-sépticas. RGO 2001; 49:167-71.

25- Socransky SS, Haffajee AD, Cugini MA, Smith C, Kent RL Jr. Microbial complexes in subgingival plaque. J Clin Periodontol 1998; 25:134-44.

26- Suido H, Offenbacher S, Arnold RR. A clinical study of bacterial contamination of chlorhexidine-coated filaments of an interdental brush. J Clin Dent 1998; 9:105-9.

27- Taji SS, Rogers AH. The microbial contamination of toothbrushes. A pilot study. Aust Dent J 1998; 43:128-30.

28- Tchaou WS, Turng BF, Minah GE, Coll JA. In vitro inhibition of bacteria from root canals of primary teeth by various dental materials. Pediatr Dent 1995; 17:351-5.

29- Verran J, Leahy-Gilmartin AA. Investigations into the microbial contamination of toothbrushes. Microbios 1996; 85: 231-8.

30- Zolnowski-Casey M. An infection control procedure that is the patients responsibility. J Am Dent Assoc 1998; 129:616-7. 